\title{
Histomorphologic Profile of Skin Tumors
}

\author{
Rupendra Thapa, ${ }^{2}$ Pranita Gurung, ' Suspana Hirachand, ' Sanju Babu Shrestha \\ 'Department of Pathology, Kathmandu Medical College Teaching Hospital, Sinamangal, Kathmandu, Nepal, ${ }^{2}$ Department of \\ Dermatology, Kathmandu Medical College Teaching Hospital, Sinamangal, Kathmandu, Nepal.
}

\begin{abstract}
Introduction: Skin tumors are not uncommon in the Nepalese community. Accurate diagnosis and categorization of these into different types is important because of its effect on prognosis and management. We conducted this study to find out the frequency of different histological types of skin tumors, correlate with their clinicopathologic profile and to determine the stage of malignant tumors.
\end{abstract}

Methods: This is a descriptive cross-sectional study of skin tumors during the period February 2015 to January 2017. All the patients who were subjected to skin biopsy for skin tumors were included in this study. The biopsies taken were fixed in $10 \%$ formalin and then processed. Four microns thick sections were taken and stained with Haematoxylin and Eosin stain (H\&E).

Results: Total of 108 cases of skin tumors were included of which 68 (62.97\%) cases were histologically diagnosed as benign and $40(37.03 \%)$ cases were diagnosed as malignant tumors. Keratinocytic tumors were predominant among both benign and malignant skin tumors.

Conclusions: Histopathological examination is the gold standard for accurate diagnosis and prognostic assessment of the patient. Staging of the malignant tumors in excision biopsy specimen needs to be emphasized since it is a predictor of prognosis.

Keywords: benign; histopathological; malignant; tumors.

\section{INTRODUCTION}

Skin tumors comprises a wide variety of neoplasms of skin and subcutis that are further classified as keratinocytic, melanocytic, appendageal, hematolymphoid, and soft tissue tumors. ${ }^{1}$ The incidence of skin tumors varies widely in different part of the world. The incidence of cutaneous squamous cell carcinoma and other carcinomas of the skin varies globally, but is thought to be increasing overall since the 1960s at a rate of $3-8 \%$ per year. ${ }^{2}$ The high incidence of cutaneous squamous cell carcinoma and basal cell carcinoma is thought to be mostly the result of sun exposure and mutagenic effects of ultraviolet (UV) light. ${ }^{3}$

Benign tumors are sometimes confused clinically with malignancy, particularly when they are pigmented or ulcerated or inflamed, and histologic examination of biopsy specimen is required to establish a definite diagnosis. Hence biopsy of skin tumors is the gold standard for accurate diagnosis and prognostic assessment of the patient. The knowledge of histopathological patterns can help in prognosis and planning an effective management. ${ }^{4}$

This study was undertaken to determine the frequency of different histological types of tumors of the skin, correlate with their clinicopathologic profile and to determine the stage of malignant tumors so as to prevent mortality and morbidity associated with it.

Correspondence: Dr. Rupendra Thapa, Department of Pathology, KMCTH, Sinamangal, Kathmandu, Nepal. Email: rup432@ gmail.com, Phone: +9779841201342. 


\section{METHODS}

This is a descriptive cross-sectional study of skin tumors carried out in the Department of Pathology, Kathmandu Medical College Teaching Hospital, Sinamangal, Kathmandu during a period of February 2015 to January 2017. All the patients who were subjected to skin biopsy for skin tumors were included in this study. The biopsies taken were fixed in $10 \%$ formalin and then processed. Four microns thick sections were taken and stained with Haematoxylin and Eosin stain $(H \& E)$. The tumors were classified according to World Health Organization classification of tumors-skin tumors 2006. ${ }^{1}$ Pathological staging of the malignant skin tumors was done according to the TNM system (American Joint Committee on Cancer 2010) only in excision specimen. ${ }^{5}$

Sample size required for the study was calculated by the following formula:

Sample size $(n)=z^{2 *}(p q) / e^{2}$

$$
\begin{aligned}
& =1.65 * 1.65 * 0.5 *(1-0.5) / 0.1^{2} \\
& =68
\end{aligned}
$$

where, $z=1.65$ for $\mathrm{Cl}=90 \%$.

$\mathrm{p}=$ prevalence proportion in target population to have certain character

$$
q=(1-p)
$$

$\mathrm{e}=$ allowable error

The data collected wa entered in Microsoft Excel and analysed in SPSS (Statistical Packages for Social Services). The descriptive statistical analysis was done.

\section{RESULTS}

A total of 108 skin tumors were analyzed during the study period. Spectrum of different histomorphological diagnosis of skin tumors was observed (Table 1).

Table 1. Distribution of cases according to

\begin{tabular}{|c|c|c|}
\hline & Melanocytic tumors & $21(19.44)$ \\
\hline 5. & Intradermal nevus & 18 (16.67) \\
\hline \multirow[t]{2}{*}{6.} & Compound nevus & $3(2.78)$ \\
\hline & Appendageal tumors & $13(12.03)$ \\
\hline 7. & Pilomatricoma & $4(3.70)$ \\
\hline 8. & Tricholemmoma & $3(2.78)$ \\
\hline 9. & $\begin{array}{l}\text { Syringocystadenoma } \\
\text { papilliferum }\end{array}$ & $2(1.86)$ \\
\hline 10. & Chondroid syringoma & $1(0.93)$ \\
\hline 11. & Cylindroma & $1(0.93)$ \\
\hline 12. & Poroma & $1(0.93)$ \\
\hline \multirow[t]{2}{*}{13.} & Sebaceoma & $1(0.93)$ \\
\hline & Soft tissue tumors & $4(3.70)$ \\
\hline 14. & Angiokeratoma & $2(1.86)$ \\
\hline 15. & Dermatofibroma & $1(0.93)$ \\
\hline \multirow[t]{3}{*}{16.} & Capillary hemangioma & $1(0.93)$ \\
\hline & MALIGNANT TUMORS & $40(37.03)$ \\
\hline & Keratinocytic tumors & $29(26.86)$ \\
\hline 17. & Squamous cell carcinoma & $17(15.74)$ \\
\hline \multirow[t]{2}{*}{18.} & Basal cell carcinoma & $12(11.11)$ \\
\hline & Melanocytic tumors & $9(8.33)$ \\
\hline \multirow[t]{2}{*}{19.} & Malignant melanoma & $9(8.33)$ \\
\hline & Appendageal tumors & $2(1.86)$ \\
\hline 20. & $\begin{array}{l}\text { Proliferating tricholemmal } \\
\text { tumor }\end{array}$ & $1(0.93)$ \\
\hline \multirow[t]{2}{*}{21.} & Sebaceous carcinoma & $1(0.93)$ \\
\hline & Total & $108(100)$ \\
\hline
\end{tabular}
histomorphological diagnosis.

\begin{tabular}{|lll|}
\hline S. N. Histomorphological diagnosis & $\begin{array}{l}\text { No.of cases } \mathbf{n} \\
(\%)\end{array}$ \\
& BENIGN TUMORS & $68(62.97)$ \\
1. & Seratinocytic tumors & $30(27.78)$ \\
2. & Verruca vulgaris & $17(15.74)$ \\
3. & Squamous papilloma & $8(7.40)$ \\
4. & Keratoacanthoma & $3(1.86)$
\end{tabular}

Out of 108 skin tumors, 68 tumors were benign and 40 tumors were malignant. The benign tumors were more common than malignant tumors with benign to malignant ratio of $1.7: 1$. Among the benign tumors 41 cases were female and 27 cases were male with female to male ratio of $1.5: 1$. Female preponderance was observed in benign tumors but there was male preponderance in malignant tumors where 27 cases 
Thapa et al. Histomorphologic Profile of Skin Tumors

were male and 13 cases were female with male to female ratio of 2.07:1 (Table 2).

\begin{tabular}{|c|c|c|c|c|c|c|c|c|c|}
\hline S.N. & Malignant tumors & $<40$ years & $\begin{array}{l}41-50 \\
\text { years }\end{array}$ & $\begin{array}{l}51-60 \\
\text { years }\end{array}$ & $\begin{array}{l}61-70 \\
\text { years }\end{array}$ & $\begin{array}{l}71-80 \\
\text { years }\end{array}$ & $\begin{array}{l}\text { Total } \\
\text { n (\%) }\end{array}$ & $\mathbf{M}$ & $\mathbf{F}$ \\
\hline 1. & $\begin{array}{l}\text { Squamous cell } \\
\text { carcinoma }\end{array}$ & 0 & 1 & 4 & 9 & 3 & $17(42.5)$ & 12 & 5 \\
\hline 2. & Basal cell carcinoma & 1 & 2 & 3 & 5 & 1 & $12(30)$ & 7 & 5 \\
\hline 3. & Malignant melanoma & 0 & 0 & 3 & 5 & 1 & $9(22.5)$ & 7 & 2 \\
\hline 4. & Sebaceous carcinoma & 0 & 0 & 1 & 0 & 0 & $1(2.5)$ & 1 & 0 \\
\hline \multirow[t]{2}{*}{5.} & $\begin{array}{l}\text { Proliferating } \\
\text { tricholemmal tumor }\end{array}$ & 0 & 1 & 0 & 0 & 0 & $1(2.5)$ & 0 & 1 \\
\hline & Total & 1 & 4 & 11 & 19 & 5 & $40(100)$ & 27 & 13 \\
\hline
\end{tabular}

Age of the study population ranged from 16 to 80 years. The peak incidence was seen between 41 to 50 years in benign tumors where as in malignant tumors it was seen in between 61 to 70 years (Table 2). Clinically most cases presented as nodules and ulcerated swelling. Head and neck region, particularly the face was commonly involved (Table 3).

\begin{tabular}{|c|c|c|c|}
\hline S.N. & Skin tumors & No.of cases & Site of involvement \\
\hline 1 & Seborrhoeic keratosis & 17 & Scalp (5), Neck (4), Back (3), Chest wall (3), Leg (2) \\
\hline 2 & Verruca vulgaris & 8 & Face (3), Neck (2), Foot (2), Arm(1) \\
\hline 3 & Squamous papilloma & 2 & Lip (1), Back (1) \\
\hline 4 & Keratoacanthoma & 3 & Neck (2), Chin (1) \\
\hline 5 & Intradermal nevus & 18 & Face (7), Neck (4), Arm(3), Back(4) \\
\hline 6 & Compound nevus & 3 & Face (3) \\
\hline 7 & Pilomatricoma & 4 & Neck (3), Back (1) \\
\hline 8 & Tricholemmoma & 3 & Scalp (2), Neck (1) \\
\hline 9 & $\begin{array}{l}\text { Syringocystadenoma } \\
\text { papilliferum }\end{array}$ & 2 & Neck (1), Back (1) \\
\hline 10 & Chondroid syringoma & 1 & Face (1) \\
\hline 11 & Cylindroma & 1 & Neck (1) \\
\hline 12 & Poroma & 1 & Inguinal region (1) \\
\hline 13 & Sebaceoma & 1 & Postauricular region (1) \\
\hline 14 & Angiokeratoma & 2 & Back (1), Vulva (1) \\
\hline 15 & Dermatofibroma & 1 & Chest wall (1) \\
\hline 16 & Capillary hemangioma & 1 & Back (1) \\
\hline 17 & Squamous cell carcinoma & 17 & Face (5), Lip (3), Scalp (2), Arm (2), Chest wall (2), Leg (3) \\
\hline 18 & Basal cell carcinoma & 12 & Nose (4), Cheek (3), Forehead (3), Lip (2) \\
\hline 19 & Malignant melanoma & 9 & Foot (4), Thigh (2), Arm (1), Toe (1), Scalp (1) \\
\hline 20 & $\begin{array}{l}\text { Proliferating tricholemmal } \\
\text { tumor }\end{array}$ & 1 & Scalp (1) \\
\hline
\end{tabular}


Amongst the benign category maximum number of cases comprised of keratinocytic tumors 30 cases $(27.78 \%)$ and in malignant category also it was keratinocytic tumors $29(26.86 .5 \%)$ cases (Table $1)$. Out of 40 malignant skin tumors squamous cell carcinoma was the most common tumor comprising of $17(42.5 \%)$ cases followed by basal cell carcinoma 12 $(30 \%)$ cases, malignant melanoma $9(22.50 \%)$ cases, proliferating tricholemmal tumor $1(2.5 \%)$ case and sebaceous carcinoma 1 (2.5\%) case (Table 2). As per TNM staging used in our study majority of squamous cell carcinomas were in pT2 stage whereas majority of basal cell carcinomas were in pT1 stage. In case of malignant melanoma majority were in stage $\mathrm{pT} 4 \mathrm{~b}$ (Table 4).

Table 4. Histological staging of malignant tumors as per TNM staging.

\begin{tabular}{|llllll|}
\hline S.N. Staging & & \multicolumn{2}{c|}{ No. of cases } & Total \\
& & & $\begin{array}{l}\text { Squamous } \\
\text { cell } \\
\text { carcinoma }\end{array}$ & $\begin{array}{l}\text { Basal cell } \\
\text { carcinoma }\end{array}$ & Malignant \\
1 & pT1 & 3 & 6 & 0 & 9 \\
2 & pT2 & 7 & 2 & 0 & 9 \\
3 & pT3b & 0 & 0 & 1 & 1 \\
4 & pT4b & 0 & 0 & 4 & 4 \\
& Total & 10 & 8 & 5 & 23 \\
\hline
\end{tabular}

\section{DISCUSSION}

Keratinocytic tumors are an important public health problem, despite their comparatively low mortality rate. There is an increasing incidence of squamous cell carcinoma of the skin in some countries. Keratinocytic tumors account for approximately $90 \%$ or more of all skin malignancies, of which approximately $70 \%$ are basal cell carcinomas. ${ }^{1}$ In view of various studies on skin tumors it seems that the incidence of squamous cell carcinoma is more in our part of the world..$^{6-9}$ In present study the keratinocytic tumors, both benign accounting for $30(27.78 \%)$ cases and malignant accounting for
$29(26.86 \%)$ cases were the common tumors of skin. Among the malignant keratinocytic tumors majority was squamous cell carcinoma $17(15.74 \%)$ cases followed by basal cell carcinoma $12(11.11 \%)$ cases. The demographic characteristics of the patients in current study were relatively similar to a number of studies which describe a peak incidence of malignant skin tumors in the age 61-70 years and preponderance in male with male to female ratio of $2.07: 1.6,7,10$

In current study, the incidences of benign and malignant tumors were $68(62.27 \%)$ cases and 40 (37.03\%) cases. This findings were comparable the study done by Har-Shai et al. and Rajinder Kaur et al. ${ }^{11,12}$

In our study majority of squamous cell carcinomas were in pT2 stage whereas basal cell carcinomas were in pT1 stage. In case of malignant melanoma, majority were in stage pT4b as shown (Table 4). It has been said that $\mathrm{BCC}$ s rarely require staging given their minimal potential for metastasis. However, cutaneous SCC has a $4 \%$ annual incidence of metastasis, so staging is vital to its management and treatment. ${ }^{13}$

The location of SCC and BCC in our study was seen predominantly on face and nose which was in concordance with study done by Koyuncuer A. Ulceration was seen in majority of cases in current study which was also observed in the above mentioned study. ${ }^{14}$ Due to cosmetic purpose patient would like to remove lesions of the face so this could be one of the reason for the face being the common site of presentation in our study. Among the benign tumors intradermal nevus $18(16.67 \%)$ cases was the predominant tumors which is comparable with the study done by Gundalli $\mathrm{S}$ et al. ${ }^{10}$

\section{CONCLUSIONS}

This study revealed a wide spectrum of neoplastic lesions of skin. Majority of cases were benign tumors and among the malignant tumors, squamous cell carcinoma was predominant followed by basal cell carcinoma. Staging of the malignant tumors in excision biopsy specimen especially for squamous cell carcinoma needs to be emphasized since it is a predictor of prognosis.

\section{Conflict of Interest: None.}

\section{REFERENCES}

1. Le Boit PE, Burg G, Weedon D and Sarasain A. Pathology and Genetics of Skin Tumours : World Health Organization Classification of Tumours. 3rd ed. Lyon: IARC Press; 2006. 9-164 p. [Full Text]
2. Diepgen TL, Mahler V. The epidemiology of skin cancer. Br J Dermatol. 2002 Apr;146( Suppl 61):1-6. [PubMed] 
3. Preston DS, Stern RS. Non-melanoma cancers of the skin. N Engl J Med. 1992;327:1649-62. [Full Text | DOI]

4. Reddy MK, Veliath AJ, Nagarajan S, Aurora AL. Clinicopathological study of adnexal tumours of skin. Indian J Med Res. 1982 Jun;75:882-889. [ Full Text]

5. Edge SB, Byrd DR, Compton CC, Fritz AG, Greene FL, Trotti A. AJCC Cancer Staging Handbook. $7^{\text {th }}$ ed. New York: Springer; 2010. Chapter 29. [Full Text]

6. Vaibhav B, Murarkar P, Gosavi A, Sulhyan K. Skin Tumours-Histopathological Review of 125 Cases. Indian Medical Gazette. 2014 Nov;417-428. [Full Text]

7. Budharaja SN, Pillai VC, Periyanagam WJ, Kaushik SP, Bedi BMS. Malignant neoplasms of skin in Pondicherry-A study of 102 cases. Indian J Cancer. 1972 Dec;9(4):284-95. [PubMed]

8. Charkravorthy RC, Choudhuri DR. Malignant neoplasms of the skin in Eastern India. Indian J Cancer. 1968;(5):133-144. [Full Text]

9. Deo SV. Surgical management of skin cancers: Experience from a regional cancer centre in North India. Indian J Cancer. 2005;42:145-50. [PubMed | Full Text]
10. Gundalli S, Kolekar R, Pai K, Kolekar A. Histopathological Study of Skin Tumours. International Journal of Healthcare Sciences. 2014 Oct -2015 Mar;2(2):155-163. [Full Text]

11. Har-Shai Y, Hai N, Taran A, Mayblum S, Barak A, Tzur E, et al. Sensitivity and positive predictive values of presurgical clinical diagnosis of excised benign and malignant skin tumours: a prospective study of 835 lesions in 778 patients. Plast Reconstr Surg. 2001 Dec;108(7):1982-9. [PubMed | Full Text]

12. Kaur R, Kumar V, Mehra K, Gupta N, Singh A. Histopathological evaluation of Skin Tumours. Indian Journal of Pathology and Oncology. 2016 Oct-Dec;3(4):627-631. [Full Text]

13. Fahradyan A, Howell CA, Wolfswinkel ME, Tsuha M, Sheth P, Wong AK. Updates on the Management of Non- Melanoma Skin Cancer (NMSC). Healthcare (Basel). 2017 Nov 1;5(4):82.

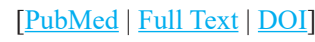

14. Koyuncuer A. Histopathological evaluation of non-melanoma skin cancer. World Journal of Surgical Oncology. 2014;12:159. [피l Text]

The Author(s) 2018.

This work is licensed under a Creative Commons Attribution 4.0 International License. The images or other third party material in this article are included in the article's Creative Commons license, unless indicated otherwise in the credit line; if the material is not included under the Creative Commons license, users will need to obtain permission from the license holder to reproduce the material. To view a copy of this license, visit http://creativecommons.org/licenses/by/4.0/ 